\title{
Amadeus
}

International Multidisciplinary Journal ISSN 2525-8281

DOI: $10.14295 /$ aimj.v4i7.73

\section{Mucosal Injuries by Tegumentary Leishmaniasis: A Systematic Review}

Pedro Walisson Gomes

Feitosa $^{l}$;

Italo Constancio de Oliveira ${ }^{2}$

Rayane da Silva Moura ${ }^{3}$

Yasmin de Alencar Grangeiro ${ }^{4}$

Elisa Hellen Cruz Rodrigues ${ }^{5}$,

Heloísa Fernandes Caracas ${ }^{6}$.

Sally de França Lacerda

Pinheiro $^{7}$
Abstract: American Tegumentary Leishmaniasis (ATL) it's the name given to the amount of infection diseases that cause immunological and polymorphic changes on the skin and mucosa. Caused by the contamination of protozoa of the genus Leishmania, the pathogenesis in question can manifest itself in the Tegumentary (mucosa and cutaneous) and in the visceral form, depending on the parasite and the host. The aim of this study was to collect the scientific knowledge produced about the Mucosa Tegumentary Leishmaniasis, presenting the epidemiological, clinical, diagnostic and therapeutic relations available in the researched literature. It was applied the Muños Protocol (2002) in published articles between 1981 and 2018 and indexed in the database of the Health Virtual Library (HVL) that was selected for this review study. The research strategy used was: "Tegumentary Leishmaniasis" and "Mucosa", including, too, the following limits: articles in Portuguese, English and Spanish, available. The works present interfaces of Mucosa Tegumentary Leishmaniasis, stating epidemiological, clinical, diagnostic and therapeutic data of the pathology. It is evidenced the importance of the realization of studies about this theme to the development of new medical treatments. It is noticed that there is still a limited number of researches in this field, becoming necessary new studies about the theme.

Keywords: Mucosal injuries. Leishmaniasis. Infection diseases.

\footnotetext{
${ }^{1}$ Medical Student at Federal University of Cariri. Barbalha/CE, Brasil. gomesfeitosa.walisson@ outlook.com;

${ }^{2}$ Medical Student at Federal University of Cariri. Barbalha/CE, Brasil. italo.constancio@ outlook.com;

${ }^{3}$ Medical Student at Federal University of Cariri. Barbalha/CE, Brasil. rayanesilvamed@ gmail.com;

${ }^{4}$ Graduated in Biomedicine from Leão Sampaio Juazeiro do Norte University Center/CE, Brasil. yasmindealencar@live.com;

${ }^{5}$ Medical Student at Federal University of Cariri. Barbalha/CE, Brasil.elisacruz24@gmail.com;

${ }^{6}$ Law Student from the Regional University of Cariri. Crato/CE, Brasil. helocfernandes@ hotmail.com;

${ }^{7} \mathrm{PhD}$ in Health Sciences from Descartes University of Paris, Associate Professor at Federal University of Cariri. Barbalha/CE, Brasil. sallylacerda@ hotmail.com.
} 


\section{Introduction}

The American Tegumentary Leishmaniasis (ATL) is a zoonosis of wild animals, mainly rodents, being transmitted by certain species of sand flies of tropical forests (Amato, 1996). This infectious and non-contagious disease presents manifestation polymorphic on the skin and mucosa caused by many protozoan of the genus Leishmania, being the most common in Brazil the Leishmania (Viannia) guyanensis, L. (Viannia) braziliensis, and L. (Leishmania) amazonensis (Murback 2011). Those are transmitted for the sting of insects of the genus Lutzomya, and who develops the form of promastigotes, while in the mammal host its morphology corresponds to the amastigote, parasite intracellular macrophage (Telmo, 2012).

The disease can be presented in the located cutaneous (LC) form, cutaneous disseminated (LCD), cutaneous diffuse (LCD) and mucosa (LM), with or without injuries on the skin. The Mucosa Leishmaniasis (ML) occurs in a percentage that varies in three to $5 \%$ of the infectious cases by L. (V) braziliensis; it is graver and can leave sequels (Velozo, 2006). In order of frequency, the mucosa injuries manifest themselves, mainly, on the nose, hard palate, pharynx and larynx, where can present itself with erythematousinfiltrated, granulose, ulcerated or polypoid aspect, with roughly shrouded surface (Neto, 2008). Can be complicated for infections as rhinitis, sinusitis, meningitis and bronchopneumonia, being this last the principal responsible for the obit (Marsden, 1986). This commitment can leave to the perfusion of the nasal septum, destruction of the nasal mucosa, labial, soft palate, pharynx and larynx (Silva, 2007).

The lymphatic metastasis or hematogenous of local cutaneous parasites of inoculation for the nasopharyngeal mucosa is considered the subjacent cause of the mucosa disease (Figueroa, 2009). The association of the infection by L. braziliensis with this form of the disease suggests that, beside the host, related factors to the parasite be relevant for the development of the mucosa disease (Lessa 2007). Previous studies has been calling attention to that constitute themselves risk factors to the mucosa leishmaniasis development the presence of injuries above the pelvic waist, cutaneous ulcers of a big size and inappropriate treatment to the cutaneous Leishmaniasis (Carvalho, 1994).

The condition of the skin and the auricular cartilage occurs for being a place with a lower temperature, conducive to the leishmaniasis growth, besides being an exposed area to the inoculation of the vectors (Ecco, 2000). The association of lower temperature with 
leishmaniasis can be, in part, be explained for the documentation in vitro that the macrophages cultivated in the temperature of $29^{\circ}$ Celsius with a minor capacity of destructing leishmaniasis than the macrophages cultivated in $33^{\circ}$ Celsius (Scott, 1985). The specific destruction of nasal cartilage can also indicate autoimmune reaction, what would explain why some patients attend with intense tissue destruction meanwhile others just present the mucosa impairment decades later (Marsden, 1986). The cartilage commitment of the epiglottis and the arytenoids can occur like in the cartilaginous septum, in a bigger or smaller intensity, making the swallowing extremely painful, by the established perichondritis in these circumstances (Lessa, 1999).

The mucosa Leishmaniasis diagnosed are limited by the invasiveness and limited sensibility of the methods of biopsy and histopathology, as well the fact that these methods require qualified medical specialists (Figueroa, 2009). Thus, this work objectives to reunite the scientific knowledge produced about the Mucosa Tegumentary Leishmaniasis, presenting the epidemiologic, clinical, diagnostic and therapeutic relations, available in the researched literature.

\section{Methodology}

Published articles between 1981 and 2018 and indexed in the database of the Health Virtual Library (HVL) were selected for this review work. The research strategy used was: "Tegumentary Leishmaniasis" and "Mucosa", being included, also, the following limits: portuguese, english and spanish articles, available in full. Were excluded revision articles, as well literature comments, editorials, communications and letters to the editor. The research period of the articles occurred between october 20th of 2018 and november 1 st of 2018.

The articles selection was realized by two evaluators and, in the case of disagreements, the third examiner was summoned for the final consent. Each article was read in full and its information were disposed in a spreadsheet, including the publication year, authors, database and periodic. Then, the works were summited to three relevance tests composed by objective questions, that analyze the article relation with the proposed objectives for the consonant research descript by Muñoz et al., 2002.

The first relevance test consisted in the following questions: Does the study agree with the investigated theme? Was the published study stipulated in the project? Was the study 
published in the language stipulated in the project? Does the study approach the solution of the problem that it is being investigated? Was the study included in?

The second test objectives to verify the methodology finality used for the study, having the following questions: Is the research problem clear? Do the objectives of the study have relation with the studied question? Is the methodology descript with clarity and approach all the objectives? Are the results compatible with the used methodology? There is accuracy in the employed results? Was the study included in?

In the relevance test, were extracted detailed information of each selected article, distributing them in a spreadsheet with the following questions: (a) Main theme; (b) Research type; (c) Study sample; (d) Adopted Methodology; (e) Statistical Analysis; (f) Results; (g) Conclusion. For the data studies, the following stage involved the information division obtained starting from the lecture of each one of the works in three categories: epidemiology, clinic and therapeutic.

\section{Results}

Among the 79 articles identified initially in the electronic search, only 24 articles were included in the final sample after the relevance tests and criteria analyze fully (Figure 1). The obtained references describe clinic evolutions, therapeutic methods and epidemiologic analyzes about mucosa injuries by Tegumentary Leishmaniasis (Table 1).

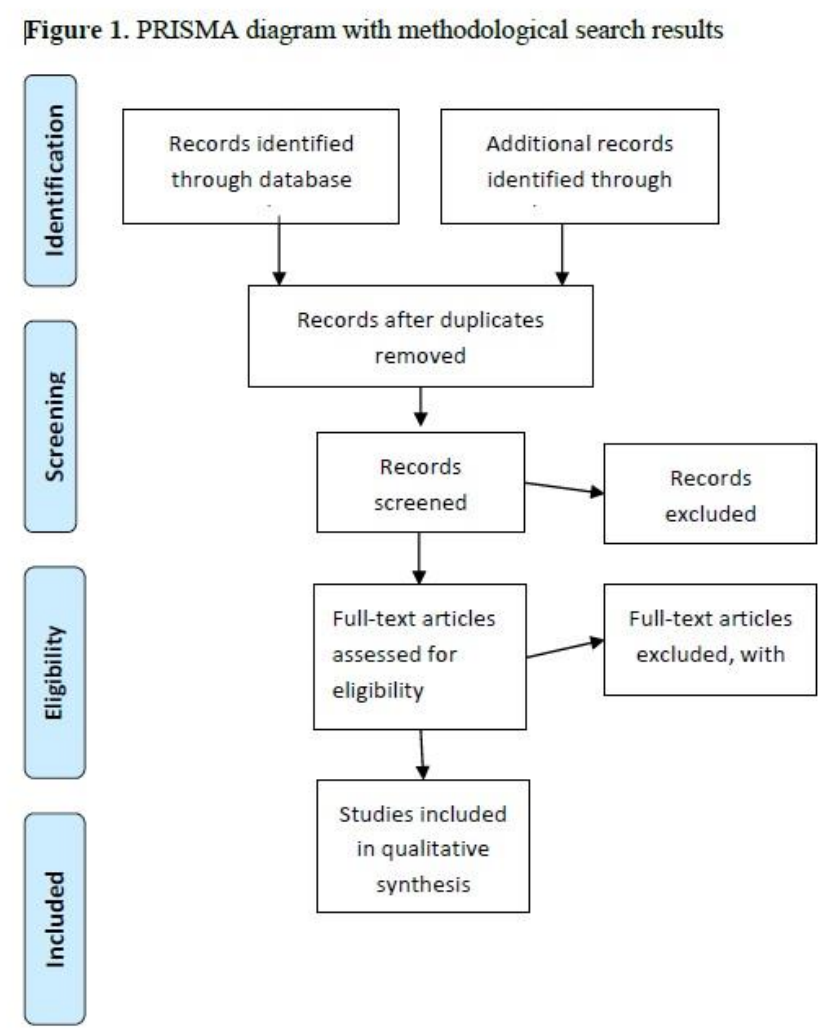


Table 1. Results by selected article

\begin{tabular}{|c|c|c|c|c|c|}
\hline Author and year & Magazine & Objective & Methodology & Results & Conclusion \\
\hline $\begin{array}{c}\text { Padilha; } \\
\text { Albuquerque;Pedro } \\
\text { sa, 2010. }\end{array}$ & $\begin{array}{c}\text { Pan- } \\
\text { Amazônica } \\
\text { Health } \\
\text { Magazine }\end{array}$ & $\begin{array}{l}\text { Evaluate the } \\
\text { dinamic of the } \\
\text { endemy and to } \\
\text { plan measures of } \\
\text { control, objecting } \\
\text { lowing its impact } \\
\text { on the population. }\end{array}$ & $\begin{array}{l}\text { The epidemiologic } \\
\text { indicators of the } \\
\text { American Tegumentary } \\
\text { Leishmaniasis of the } \\
\text { Health Ministry, } \\
\text { collected in a timeline of } \\
10 \text { years, has been } \\
\text { quantified and evaluated. }\end{array}$ & $\begin{array}{l}\text { There was the surging of } 1.338 \\
\text { new cases where among them, } \\
1.097 \text { of the involved patients } \\
\text { possessed age equal or bigger } \\
\text { than } 10 \text { years. About the sex, } 525 \\
\text { patients were from the feminine } \\
\text { sex and } 811 \text { were from the } \\
\text { masculine sex. In } 2007 \text { there was } \\
\text { a peak of the disease where it was } \\
\text { diagnosed in } 969 \text { patients in its } \\
\text { cutaneous form. It was realized, } \\
\text { then, } 625 \text { dermic reactions of } \\
\text { Montenegro, obtaining, in } 2008, \\
\text { the maximum value of } 88,1 \% \text { of } \\
\text { the cases. }\end{array}$ & $\begin{array}{l}\text { In Alagoas it was } \\
\text { detected a bigger } \\
\text { prevalence of the } \\
\text { disease in men older } \\
\text { than } 10 \text { years old. } \\
\text { Besides, the } \\
\text { cutaneous form was } \\
\text { the most founded. } \\
\text { Knowing the } \\
\text { situation of the } \\
\text { Leishmaniasis in } \\
\text { Alagoas, helps the } \\
\text { decision taking in } \\
\text { public health in the } \\
\text { State. }\end{array}$ \\
\hline Oliveira, 2011. & & $\begin{array}{l}\text { To evaluate the } \\
\text { genetic diversity } \\
\text { of Leishmaniasis, } \\
\text { analyzing directly } \\
\text { the injuries in } \\
\text { individuals with } \\
\text { leishmaniasis, } \\
\text { including } \\
\text { individuals } \\
\text { coinfected by the } \\
\text { immunofeciscienc } \\
\text { e human virus. } \\
\end{array}$ & $\begin{array}{l}\text { Analisou-se um total de } \\
38 \text { amostras de pacientes } \\
\text { através de reações de } \\
\text { cadeia de polimerase } \\
\text { (PCR). }\end{array}$ & $\begin{array}{l}\text { The presence of DNA of the } \\
\text { parasite was evidenced in all of } \\
\text { the samples analyzed, making } \\
\text { possible the specific diagnosis. In } \\
\text { samples of patient collected at the } \\
\text { same time in the mucosa, oral and } \\
\text { nasal, there wasn't a divergence } \\
\text { in the genetic profile founded, } \\
\text { while that the genetic profiles of } \\
\text { collected samples in different } \\
\text { times in the same location were } \\
\text { different. }\end{array}$ & $\begin{array}{l}\text { The genetic and } \\
\text { statistic analysis } \\
\text { made possible to } \\
\text { affirm that the } \\
\text { genetic diversity in } \\
\text { the level of } \\
\text { intrapatients is lesser } \\
\text { than the observed } \\
\text { among the patients. }\end{array}$ \\
\hline Oliveira, 2011. & & $\begin{array}{l}\text { To characterize } \\
\text { the epidemiologic } \\
\text { profile of the } \\
\text { american } \\
\text { tegumentary } \\
\text { leishmaniasis in } \\
\text { the city of Rio } \\
\text { Branco - } \\
\text { Acre,from the } \\
\text { period of } 2000 \text { to } \\
\text { 2008. }\end{array}$ & $\begin{array}{l}\text { It was analyzed } 2671 \\
\text { cases of ATL in the city } \\
\text { of Rio Branco. The data } \\
\text { were obtained through } \\
\text { the National Grievance } \\
\text { of Notification System - } \\
\text { SINAN. }\end{array}$ & $\begin{array}{l}\text { It was verified that there was a } \\
\text { growth in the occurrence of the } \\
\text { leishmaniasis in urban habitants } \\
\text { of the city. The biggest } \\
\text { occurrence of the cases was in } \\
\text { individuals from the masculine } \\
\text { sex and the age range most } \\
\text { impaired was the economically } \\
\text { active of } 15 \text { to } 49 \text { years with } \\
67,0 \% \text { of the cases. The majority } \\
\text { of the patients with ATL } \\
\text { presented the cutaneous clinical } \\
\text { form. }\end{array}$ & $\begin{array}{l}\text { The leishmaniasis in } \\
\text { the city of Rio } \\
\text { Branco it } \\
\text { characterizes itself } \\
\text { as a transmission } \\
\text { disease mainly rural, } \\
\text { in the latter years the } \\
\text { was a growth of the } \\
\text { number of } \\
\text { notifications in the } \\
\text { urban field of the } \\
\text { city. }\end{array}$ \\
\hline Murback et., 2011. & $\begin{array}{c}\text { Brazilian } \\
\text { Dermatolog } \\
\text { y Anais }\end{array}$ & $\begin{array}{l}\text { Avaliar clínica, } \\
\text { epidemiológica e } \\
\text { laboratorialmente } \\
\text { pacientes com } \\
\text { Leishmaniose } \\
\text { Tegumentar } \\
\text { Americana, } \\
\text { atendidos no } \\
\text { Hospital } \\
\text { Universitário Maria } \\
\text { Aparecida } \\
\text { Pedrossian, } \\
\text { Universidade } \\
\text { Federal de Mato } \\
\text { Grosso do Sul, } \\
\text { Brasil. }\end{array}$ & $\begin{array}{c}\text { Foram avaliados dados } \\
\text { de pacientes suspeitos } \\
\text { de Leishmaniose } \\
\text { Tegumentar } \\
\text { Americana, de } 1998 \text { a } \\
\text { 2008, e encaminhados } \\
\text { ao Laboratório de } \\
\text { Parasitologia/ para } \\
\text { complementação } \\
\text { diagnóstica. }\end{array}$ & $\begin{array}{l}\text { Predominated men with more } \\
\text { than } 45 \text { years, with a cutaneous } \\
\text { form, with lesser than six months. } \\
\text { The commitment of the mucosa } \\
\text { was crescent with the growth of } \\
\text { the age and bigger in patients that } \\
\text { searched later treatment. }\end{array}$ & $\begin{array}{c}\text { The association of } \\
\text { parasitological and } \\
\text { immunologic exam } \\
\text { makes the } \\
\text { laboratorial } \\
\text { diagnosis more } \\
\text { secure. }\end{array}$ \\
\hline Braga, 2012. & & $\begin{array}{l}\text { Evaluate the ear } \\
\text { functions of the } \\
\text { patients with the } \\
\text { mucosa form of ATL } \\
\text { to verify the } \\
\text { frequency of the } \\
\text { tubal/otitis } \\
\text { dysfunction medium } \\
\text { with effusion and to } \\
\text { describe the factors } \\
\text { associated to it. }\end{array}$ & $\begin{array}{l}\text { The patients were } \\
\text { submitted to the } \\
\text { otorhinolaryngology } \\
\text { and speech-language } \\
\text { pathology evaluations } \\
\text { in the pre-treatment } \\
\text { consults and until a } \\
\text { month later the } \\
\text { conclusion of the } \\
\text { treatment or even the } \\
\text { normalization of the } \\
\text { alterations. }\end{array}$ & $\begin{array}{l}\text { It was included } 17 \text { patients, being } \\
15 \text { of them from the masculine } \\
\text { sex and } 2 \text { of the feminine sex. } \\
\text { The age varied from } 30 \text { to } 77 \\
\text { years. } 23,5 \% \text { presented curve } B \\
\text { or } \mathrm{C} \text { in the immitanciometric test, } \\
\text { and from these, } 2 \text { presented } \\
\text { retraction of the tympanic } \\
\text { membrane and a conductive type } \\
\text { audiometric curve. }\end{array}$ & $\begin{array}{l}\text { These results made } \\
\text { visible the } \\
\text { importance of the } \\
\text { realization of an } \\
\text { otoscopic evaluation } \\
\text { and audiometric and } \\
\text { immitanciometric } \\
\text { exams before and } \\
\text { after the treatment of } \\
\text { patients with } \\
\text { mucosal } \\
\text { leishmaniasis }\end{array}$ \\
\hline
\end{tabular}




\begin{tabular}{|c|c|c|c|c|c|}
\hline Viana et al., 2012. & $\begin{array}{l}\text { Medicine } \\
\text { Magazine of } \\
\text { minas } \\
\text { Gerais }\end{array}$ & $\begin{array}{l}\text { To know the } \\
\text { patients' profile with } \\
\text { cutaneous } \\
\text { leishmaniasis in the } \\
\text { city of Montes } \\
\text { Claros - MG. }\end{array}$ & $\begin{array}{l}\text { It was realized a data } \\
\text { collect in the files of } \\
\text { the Grievance and } \\
\text { Notification of the } \\
\text { National System of } \\
\text { the patients with } \\
\text { cutaneous } \\
\text { leishmaniasis, in the } \\
\text { period of } 2002 \text { to } \\
2010 .\end{array}$ & $\begin{array}{l}\text { The notifications were from } 446 \\
\text { patients, being } 283 \text { men and } 163 \\
\text { women. The age of the patients } \\
\text { varied between } 1 \text { and } 90 \text { years. } \\
\text { The clinical form predominant } \\
\text { was the cutaneous, being } \\
\text { registered new cases of the } \\
\text { disease. In the diagnosis, the } \\
\text { intradermic reaction of } \\
\text { Montenegro presented positive } \\
\text { cases in } 281 \text { patients in } 308 \\
\text { realized tests. }\end{array}$ & $\begin{array}{l}\text { It was concluded } \\
\text { that thecutaneous } \\
\text { leishmaniasis are in } \\
\text { growth in the city } \\
\text { and that there is the } \\
\text { necessity of creating } \\
\text { a conscientization } \\
\text { program of the } \\
\text { population about the } \\
\text { expation of the } \\
\text { disease in the last } \\
\text { years. . }\end{array}$ \\
\hline Dorta et al., 2012. & $\begin{array}{c}\text { Experiment } \\
\text { al } \\
\text { Parasitology }\end{array}$ & $\begin{array}{l}\text { To compare the } \\
\text { efficiency of the } \\
\text { methods of isolation } \\
\text { of parasites ex vivo } \\
\text { and in vivo. }\end{array}$ & $\begin{array}{c}\text { Biopsy fragments of } \\
\text { cutaneous injuries or } \\
\text { mucosa were } \\
\text { inoculated in the } \\
\text { middle of cultures or } \\
\text { in the rat's paw. It was } \\
\text { evaluated } 114 \text { samples } \\
\text { using both methods } \\
\text { independently. }\end{array}$ & $\begin{array}{l}\text { Patient samples with LC had an } \\
\text { isolation rate higher in ex vivo } \\
\text { cultures than in in vivo. However, } \\
\text { almost twice the number of LM } \\
\text { injury isolated was isolated using } \\
\text { a rat model in comparation with } \\
\text { isolated ex vivo cultures. }\end{array}$ & $\begin{array}{l}\text { Use of genetically } \\
\text { modified rats can } \\
\text { improve the } \\
\text { isolation of } \\
\text { parasites. Isolation } \\
\text { and stocking of } \\
\text { parasites, are critical } \\
\text { to evaluate the } \\
\text { genetic diversity of } \\
\text { the parasite, as well } \\
\text { to study the host- } \\
\text { parasite interactions } \\
\text { to identify biological } \\
\text { markers of } \\
\text { Leishmaniasis. }\end{array}$ \\
\hline Oliveira, 2013. & & $\begin{array}{l}\text { To describe the } \\
\text { nutritional status of } \\
\text { adult and senior } \\
\text { patients with } \\
\text { american } \\
\text { tegumentary } \\
\text { leishmaniasis. }\end{array}$ & $\begin{array}{l}\text { It was realized a study } \\
\text { with } 68 \text { adult and } \\
\text { senior patients with } \\
\text { ATL in the period of } \\
2009 \text { to } 2012 \text {. The } \\
\text { nutritional evaluation } \\
\text { was realized through } \\
\text { the weight, height, } \\
\text { Corporal Mass Index } \\
\text { and serum albumin. }\end{array}$ & $\begin{array}{l}\text { Most of the samples were } \\
\text { composed by men, adults with a } \\
\text { grade of instruction of } \\
\text { fundamental incomplete. The } \\
\text { predominant form of ATL was } \\
\text { the cutaneous and } 39 \% \text { presented } \\
\text { comorbidities. The clinic and } \\
\text { nutritional complications were } \\
\text { reduced recently in the ingestion } \\
\text { of food, nasal obstruction, oral } \\
\text { ulcer and anorexia. }\end{array}$ & $\begin{array}{l}\text { The serum albumin } \\
\text { diminution affected } \\
\text { negatively the injury } \\
\text { healing, suggesting } \\
\text { that a nutritional } \\
\text { intervention could } \\
\text { increase the efficacy } \\
\text { of the ATL } \\
\text { treatment. }\end{array}$ \\
\hline Vanconcellos, 2013. & & $\begin{array}{c}\text { Describe the } \\
\text { efficiency and the } \\
\text { security of the } \\
\text { meglumine } \\
\text { antimoniate } \\
\text { administrated by } \\
\text { intralesional way, } \\
\text { for the treatment of } \\
\text { cutaneous } \\
\text { leishmaniasis. }\end{array}$ & $\begin{array}{c}\text { It was realized a study } \\
\text { with patients attended } \\
\text { in the Vigilance Lab } \\
\text { in Leishmaniasis from } \\
\text { the Clinic and } \\
\text { Research Institute } \\
\text { Evandro Chagas - } \\
\text { FIOCRUZ from } 2002 \\
\text { until july of } 2011 \text { that } \\
\text { has been treated for } \\
\text { cutaneous } \\
\text { leishmaniasis with } \\
\text { intralesional } \\
\text { application of } \\
\text { meglumine } \\
\text { antimoniate. } \\
\end{array}$ & $\begin{array}{l}\text { The meglumine antimoniate } \\
\text { administrated intralesional way } \\
\text { had minimum adverse effects. } \\
\text { Not having necessity of changing } \\
\text { the drug to others with a harder } \\
\text { administration and high cost, and } \\
\text { without developing the mucosa } \\
\text { injuries. }\end{array}$ & $\begin{array}{l}\text { Patients with } \\
\text { cutaneous } \\
\text { leishmaniasis } \\
\text { presented good } \\
\text { therapeutic response } \\
\text { to the meglumine } \\
\text { antimoniate } \\
\text { administrated by } \\
\text { intralesional way. }\end{array}$ \\
\hline Ruas, 2014. & & $\begin{array}{l}\text { Describe the vocal } \\
\text { alterations in LM } \\
\text { and evaluate the } \\
\text { speech therapy } \\
\text { effects in the } \\
\text { rehabilitation of the } \\
\text { disease. }\end{array}$ & $\begin{array}{l}\text { In the first article it } \\
\text { was realized a study } \\
\text { with } 26 \text { patients with } \\
\text { LM in activity, } \\
\text { accompanied in the } \\
\text { Clinic Research } \\
\text { Institute Evandro } \\
\text { Chagas - Fiocruz, in } \\
\text { the period from } 2010 \\
\text { to } 2013 \text {. In the second } \\
\text { article, was realized } \\
\text { an intervention speech } \\
\text { therapy study between } \\
2010 \text { and } 2012 \text {, in } 16 \\
\text { patients that presented } \\
\text { favorable answer to } \\
\text { the treatment for LM } \\
\text { in the Vigileish } \\
\text { between } 2005 \text { and } \\
2009 \text {. }\end{array}$ & $\begin{array}{l}\text { The middle ages were the } 55 \\
\text { years being } 81 \% \text { from the } \\
\text { masculine sex. The injuries } \\
\text { founded itself distributed in the } \\
\text { nasal, oral, pharynx and larynx } \\
\text { cavity. The main complain } \\
\text { referred was nasal obstruction } \\
\text { followed by dysphonia, } \\
\text { odynophagia and dysphagia. }\end{array}$ & $\begin{array}{c}\text { Even after LM drug } \\
\text { treatments, } \\
\text { approximately } 70 \% \\
\text { of the patients } \\
\text { remain with vocal } \\
\text { alterations, } \\
\text { suggesting that } \\
\text { exclusive drug } \\
\text { treatment may not } \\
\text { be sufficient for } \\
\text { voice } \\
\text { reestablishment. }\end{array}$ \\
\hline
\end{tabular}




\begin{tabular}{|c|c|c|c|c|c|}
\hline Costa, 2014. & & $\begin{array}{c}\text { Evaluate the } \\
\text { frequency of } \\
\text { occurrence of oral } \\
\text { injuries of ATL to } \\
\text { describe its clinical, } \\
\text { laboratory, } \\
\text { therapeutic } \\
\text { peculiarities. }\end{array}$ & $\begin{array}{l}\text { A study was carried } \\
\text { out using data } \\
\text { obtained from medical } \\
\text { records and clinical } \\
\text { examination of the } \\
\text { mucosa of the upper } \\
\text { aerial-digestive tracts } \\
\text { of } 206 \text { patients with } \\
\text { Mucosa } \\
\text { Leishmaniasis, } \\
\text { assisted at IPEC - } \\
\text { Fiocruz between } 1989 \\
\text { and } 2013 \text {. }\end{array}$ & $\begin{array}{l}\text { There was a prevalence of the } \\
\text { male gender among the patients } \\
\text { with the mucosal form. It was } \\
\text { possible to determine that the } \\
\text { most affected mucosal site is } \\
\text { nasal, followed by oral, } \\
\text { pharyngeal and laryngeal mucosa. }\end{array}$ & $\begin{array}{l}\text { Considering the } \\
\text { worse therapeutic } \\
\text { results associated } \\
\text { with the presence of } \\
\text { oral injuries, it is } \\
\text { suggested that } \\
\text { injuries at this } \\
\text { location represent a } \\
\text { worse prognostic } \\
\text { factor for LM. }\end{array}$ \\
\hline Galdino et al., 2014. & $\begin{array}{c}\text { BMC } \\
\text { Infectious } \\
\text { Diseases }\end{array}$ & $\begin{array}{c}\text { Evaluate the } \\
\text { expression. Of IL-32 } \\
\text { in cutaneous and } \\
\text { mucosal injuries, as } \\
\text { well as in peripheral } \\
\text { blood mononuclear } \\
\text { cells exposed to } \\
\text { Leishmania } \\
\text { braziliensis. }\end{array}$ & $\begin{array}{l}\text { IL- 32, tumor necrosis } \\
\text { factor and IL-10 } \\
\text { protein expression. } \\
\text { Were assessed by } \\
\text { immunohistochemistr } \\
\text { y in cutaneous and } \\
\text { mucosal injuries and } \\
\text { compared to healthy } \\
\text { specimens. }\end{array}$ & $\begin{array}{l}\text { Expression of IL-32 mRNA, in } \\
\text { particular IL-32y, was also } \\
\text { upregulated in injuries of patients } \\
\text { with cutaneous or mucosal } \\
\text { leishmaniasis. }\end{array}$ & $\begin{array}{l}\text { These data suggest } \\
\text { that IL-32 plays an } \\
\text { important role in the } \\
\text { inflammatory } \\
\text { process caused by } \\
\text { Leishmania sp. Or } \\
\text { that IL-32 is crucial } \\
\text { for controlling } \\
\text { infection by } \\
\text { Leishmania sp. }\end{array}$ \\
\hline $\begin{array}{c}\text { Martínez-Valencia } \\
\text { et al., 2017. }\end{array}$ & $\begin{array}{c}\text { PLoS Negl } \\
\text { Trop } \\
\text { Disease }\end{array}$ & $\begin{array}{c}\text { To investigate } \\
\text { clinical and } \\
\text { parasitological } \\
\text { parameters } \\
\text { associated with the } \\
\text { presence and } \\
\text { viability of } \\
\text { Leishmania after } \\
\text { treatment and } \\
\text { resolution of LC. }\end{array}$ & $\begin{array}{l}70 \text { patients who were } \\
\text { treated with } \\
\text { meglumine } \\
\text { antimoniate or } \\
\text { miltefosine and cured } \\
\text { were included in this } \\
\text { study. The persistence } \\
\text { and viability of } \\
\text { Leishmania were } \\
\text { determined by } \\
\text { detection of DNA and } \\
\text { RNA transcripts } \\
\text { respectively before, at } \\
\text { the end of treatment } \\
\text { and } 13 \text { weeks after } \\
\text { initiation of treatment } \\
\text { in injuries and smears } \\
\text { of nasal and tonsillar } \\
\text { mucosa. }\end{array}$ & $\begin{array}{l}70 \% \text { of the patients had evidence } \\
\text { of persistent Leishmania at the } \\
\text { 13th week after initiation of } \\
\text { treatment. An earlier episode of } \\
\text { LC has been shown to be a } \\
\text { protective factor for the } \\
\text { detectable persistence of } \\
\text { Leishmania. DNA genotyping } \\
\text { could not discern differences } \\
\text { between persistent parasite } \\
\text { populations and those isolated in } \\
\text { the diagnosis. }\end{array}$ & $\begin{array}{l}\text { Leishmania persists } \\
\text { in the tissues of the } \\
\text { skin and mucosa in a } \\
\text { high proportion of } \\
\text { patients who have } \\
\text { achieved therapeutic } \\
\text { cure for CL. This } \\
\text { finding stimulates } \\
\text { the evaluation of the } \\
\text { contribution of } \\
\text { persistent infection } \\
\text { in the transmission } \\
\text { and endemicity of } \\
\text { CL, and the } \\
\text { reactivation of } \\
\text { disease and } \\
\text { protective immunity. }\end{array}$ \\
\hline Amato et al 1995 & $\begin{array}{l}\text { Journal of } \\
\text { the } \\
\text { Brazilian } \\
\text { Society of } \\
\text { Tropical } \\
\text { Medicine }\end{array}$ & $\begin{array}{l}\text { Evalute the utility of } \\
\text { pentamidine when } \\
\text { there is mucosal } \\
\text { involvement in } \\
\text { American cutaneous } \\
\text { leishmaniasis }\end{array}$ & $\begin{array}{l}10 \text { patients with ACL, } \\
\text { who had mucosal } \\
\text { injuries, were treated } \\
\text { with pentamidine } \\
\text { isethionate at a dose } \\
\text { of } 4 \mathrm{mg} / \mathrm{kg} \text {, every } \\
\text { other day, } \\
\text { intravenously. }\end{array}$ & $\begin{array}{l}\text { The healing of the injuries } \\
\text { occurred in } 9(90 \%) \text { of the } \\
\text { patients who completed the } \\
\text { treatment. There was no relapse } \\
\text { in the follow-up period of } 1 \text { to } 24 \\
\text { months (mean of } 7,7 \text { months). }\end{array}$ & $\begin{array}{c}\text { Pentamidine } \\
\text { isethionate is } \\
\text { effective in wound } \\
\text { healing, but there is } \\
\text { a need for a better } \\
\text { evaluation of its } \\
\text { value in the } \\
\text { prevention of } \\
\text { relapses. }\end{array}$ \\
\hline $\begin{array}{c}\text { Brown, D.R. et al } \\
1996\end{array}$ & $\begin{array}{l}\text { The Journal } \\
\text { of } \\
\text { Experiment } \\
\text { al Medicine }\end{array}$ & $\begin{array}{l}\text { To assess the need } \\
\text { for NK1.1 Beta 2- } \\
\text { microglobulin- } \\
\text { dependent }+\mathrm{T} \\
\text { lymphocytes type } 2 \text {. }\end{array}$ & $\begin{array}{l}\text { It was used } 2 \text { mices } \\
\text { with deficiency of } \\
\text { beta } 2 \mathrm{~m} \text { on both } \\
\text { BALB/c and C57BL/ } \\
6 \text { backgrounds were } \\
\text { used to check their } \\
\text { ability to react by Th2 } \\
\text { cells after a series of } \\
\text { antigens stimulated by } \\
\text { various pathways. }\end{array}$ & $\begin{array}{l}\text { It was found by immunization } \\
\text { with antigens that Beta } 2 \mathrm{~m} \\
\text { deficient mice developed Th2 } \\
\text { functional responses similar to } \\
\text { wild-type mice. }\end{array}$ & $\begin{array}{l}\text { The results indicate } \\
\text { that beta } 2 \mathrm{~m}- \\
\text { dependent } \mathrm{T} \\
\text { lymphocytes are not } \\
\text { required for the } \\
\text { development of } \mathrm{Th} 2 \\
\text { in vivo. }\end{array}$ \\
\hline Enciso et al 2000 & & $\begin{array}{l}\text { To verify the osteo- } \\
\text { facial impairment of } \\
\text { human populations } \\
\text { of ancient Peru by } \\
\text { Leishmania } \\
\text { Tegumentary of } \\
\text { mucosa form. }\end{array}$ & $\begin{array}{l}\text { First, a pathological } \\
\text { pattern of LTA of a } \\
\text { mucosal form in the } \\
\text { human skull was } \\
\text { defined i patients } \\
\text { treated at the Evandro } \\
\text { Chagas Hospital } \\
\text { Research Center } \\
\text { (FIOCRUZ), with a } \\
\text { clinical History of }\end{array}$ & $\begin{array}{l}\text { The rate of } 2.07 \text { for mucosal } \\
\text { injuries compatible with ACL } \\
\text { may suggest the high prevalence } \\
\text { in a prehispanic era. }\end{array}$ & $\begin{array}{l}\text { There was therefore } \\
\text { confirmation of the } \\
\text { hypothesis and } \\
\text { indirect antecedents. }\end{array}$ \\
\hline
\end{tabular}




\begin{tabular}{|c|c|c|c|c|c|}
\hline & & & $\begin{array}{l}\text { destruction of the } \\
\text { facial mass, mainly } \\
\text { the oro-nasal cavity. } \\
\text { Then there was the } \\
\text { archaeological review } \\
\text { of } 241 \text { skulls from the } \\
\text { Inca cementery of } \\
\text { Makat-tampu, Lima, } \\
\text { Peru. }\end{array}$ & & \\
\hline Bevenuto, 2000 & & $\begin{array}{c}\text { To better understand } \\
\text { the epidemiology of } \\
\text { American Cutaneous } \\
\text { Leishmaniasis in the } \\
\text { State of Espirito } \\
\text { Santo. }\end{array}$ & $\begin{array}{c}\text { Study of the number } \\
\text { of cases occurred in } \\
\text { the period from } 1989 \\
\text { to } 1998 \text { by } \\
\text { municipality. Using } \\
\text { some types of } \\
\text { analysis, the map } \\
\text { projections were done } \\
\text { year by year } \\
\text { categorizing according } \\
\text { to the parameters used } \\
\text { by the FNS to classify } \\
\text { Low, Medium, High } \\
\text { and Very High Rates } \\
\text { and to study the } \\
\text { spatial behavior of the } \\
\text { LTA by municipality. }\end{array}$ & $\begin{array}{l}\text { The incidence in the period } \\
\text { studied varies from } 23 / 100.00 \text { in } \\
1989 \text {, increasing to } 33.09 \text { in } 1993 \text {, } \\
\text { falling progressively to } 8.7 \text { in } \\
1996 \text { and rising again to } 20.41 \text { in } \\
1998 \text {, which indicates that the } \\
\text { state has been maintained in most } \\
\text { of the years studied, in the } \\
\text { incidence range high. }\end{array}$ & $\begin{array}{l}\text { In the time series } \\
\text { studied, it was } \\
\text { observed that there } \\
\text { was no defined } \\
\text { seasonality, an } \\
\text { apparent cyclicity } \\
\text { that needs further } \\
\text { investigation has } \\
\text { been noted. }\end{array}$ \\
\hline Castro et al 2002 & $\begin{array}{c}\text { Journal of } \\
\text { the } \\
\text { Brazilian } \\
\text { Society of } \\
\text { Tropical } \\
\text { Medicine }\end{array}$ & $\begin{array}{c}\text { To know the } \\
\text { epidemiological } \\
\text { profile of cutaneous } \\
\text { leishmaniasis in the } \\
\text { Northern region of } \\
\text { Paraná. }\end{array}$ & $\begin{array}{l}\text { Survey of } 316 \text { cases of } \\
\text { the disease in } 35 \\
\text { municipalities of } \\
\text { Paraná between } 1993 \\
\text { and } 1998 .\end{array}$ & $\begin{array}{l}\text { Male subjects }(61,2 \%) \text {, aged } 15 \text { to } \\
49 \text { years }(70,8 \%) \text { accounted for } \\
\text { the majority of cases of ACL. } \\
67 \% \text { of the patients presented } \\
\text { single injuries, } 31 \% \text { multiple } \\
\text { injuries and } 2 \% \text { mucosal injuries. }\end{array}$ & $\begin{array}{l}\text { The ATL in the state } \\
\text { of Paraná is } \\
\text { characterized as } \\
\text { endemic. As an area } \\
\text { of endemism it is } \\
\text { observed that the } \\
\text { conditions in which } \\
\text { transmission occurs } \\
\text { remain stable. }\end{array}$ \\
\hline Serra et al 2003 & $\begin{array}{c}\text { Public } \\
\text { Health } \\
\text { Notebook }\end{array}$ & $\begin{array}{l}\text { To describe the } \\
\text { occurrence of LT in } \\
\text { dogs from the town } \\
\text { of Morada das } \\
\text { Aguias (Tiririca } \\
\text { Mount), Maricá, } \\
\text { State of Rio de } \\
\text { Janeiro, Brazil. }\end{array}$ & $\begin{array}{c}\text { Eighty-three dogs } \\
\text { were evaluated } \\
\text { through clinical, } \\
\text { serological and } \\
\text { parasitological } \\
\text { examination. Sera of } \\
11 \text { (13.2 percent) } \\
\text { animals were reactive } \\
\text { to indirect } \\
\text { immunofluorescence } \\
\text { (IFI) and } 30 \text { ( } 36.1 \\
\text { percent) to the } \\
\text { enzyme-linked } \\
\text { immunosorbent assay } \\
\text { (ELISA) }\end{array}$ & $\begin{array}{l}\text { Cutaneous and / or mucosal } \\
\text { ulcers were observed in } 18(\mathrm{n}= \\
83 ; 21.7 \text { percent) of the animals. } \\
\text { Leishmania was isolated from } 11 \\
\text { dogs. }\end{array}$ & $\begin{array}{l}\text { The occurrence of } \\
\text { the disease and } \\
\text { occupation of the } \\
\text { locality are } \\
\text { discussed. }\end{array}$ \\
\hline Garcia et al 2005 & $\begin{array}{c}\text { Brazilian } \\
\text { dermatology } \\
\text { anais }\end{array}$ & $\begin{array}{l}\text { To compare the } \\
\text { results of the } \\
\text { Montenegro } \\
\text { intradermalimetry } \\
\text { (MRI), presence of } \\
\text { leishmania in biopsy } \\
\text { (Bc), indirect } \\
\text { immunofluorescence } \\
\text { reaction (Rifi), DNA } \\
\text { sequencing and } \\
\text { PCR-RFLP (- } \\
\text { restriction fragment } \\
\text { lenght } \\
\text { polymorphism) for } \\
\text { the diagnosis of } \\
\text { ACL. }\end{array}$ & $\begin{array}{l}\text { Was studied } 152 \\
\text { patients with ACL. } \\
\text { For PCR in Bc, } \\
\text { specific primers were } \\
\text { used for sequence of } \\
120 \mathrm{bp} \text { of the mini } \\
\text { circle kDNA common } \\
\text { to all species of } \\
\text { leishmaniasis. The } \\
\text { PCR product, used for } \\
\text { sequencing and } \\
\text { enzymatic restriction } \\
\text { with Hae III, was } \\
\text { compared to L. (L.) } \\
\text { amazonensis and L. } \\
\text { (V.) braziliensis } \\
\text { cultures. }\end{array}$ & $\begin{array}{l}\text { There was a predominance of } \\
\text { male, white and urban } \\
\text { professionals. The age ranged } \\
\text { from three to } 77 \text { years. The } \\
\text { majority was from the State of } \\
\text { São Paulo, with the cutaneous } \\
\text { form prevailing. The MRI was } \\
\text { positive in } 73.4 \text { percent, and the } \\
\text { Rifi in } 59.7 \text { percent, while the Bc } \\
\text { showed presence of leishmania in } \\
30.6 \text { percent. PCR was positive in } \\
81.6 \text { percent, and PCR-RFLP } \\
\text { identified L. (V.) braziliensis as } \\
\text { the predominant species, which } \\
\text { also occurred with sequencing. } \\
\text { Comparing PCR-RFLP and } \\
\text { sequencing, there was agreement } \\
\text { between the results, showing } \\
\text { significance of PCR-RFLP for L. } \\
\text { (V.) braziliensis. }\end{array}$ & $\begin{array}{l}\text { MRI and PCR were } \\
\text { statistically } \\
\text { equivalent as } \\
\text { subsidiary methods } \\
\text { for the diagnosis of } \\
\text { LTA, PCR-RFLP } \\
\text { and sequencing were } \\
\text { also found in the } \\
\text { identification of } \\
\text { leishmania species, } \\
\text { the first presenting } \\
\text { lower cost and } \\
\text { execution time } \\
\text { compared to DNA } \\
\text { sequencing. }\end{array}$ \\
\hline $\begin{array}{l}\text { Oliveira-Neto, } \\
\text { Mattos, } 2006\end{array}$ & $\begin{array}{c}\text { Journal of } \\
\text { the } \\
\text { Brazilian } \\
\text { Society of } \\
\text { Tropical } \\
\text { Medicine }\end{array}$ & $\begin{array}{c}\text { To propose an } \\
\text { alternative } \\
\text { antimonial scheme } \\
\text { to be used in } \\
\text { cutaneous } \\
\text { leishmaniasis when } \\
\text { high doses of }\end{array}$ & $\begin{array}{l}\text { Use of intramuscular } \\
\text { intravenous } \\
\text { meglumine antimonia } \\
\text { ampoule every day } \\
\text { until clinical cure in a } \\
\text { series of } 40 \text { cases. The } \\
\text { total dose used per }\end{array}$ & $\begin{array}{l}\text { Of the } 40 \text { patients studied, } 36 \text { are } \\
\text { still under follow-up, with an } \\
\text { average time of } 10.7 \pm 7 \text { months } \\
\text { and an average of } 9 \text { months. } \\
\text { There were no recurrences or } \\
\text { mucosal lesions. }\end{array}$ & $\begin{array}{l}\text { The scheme was } \\
\text { well tolerated, easy } \\
\text { to apply and } \\
\text { comparable to the } \\
\text { WHO-officially } \\
\text { recommended } \\
\text { regimen, which is a }\end{array}$ \\
\hline
\end{tabular}




\begin{tabular}{|c|c|c|c|c|c|}
\hline & & $\begin{array}{c}\text { antimony are } \\
\text { undesirable }\end{array}$ & $\begin{array}{l}\text { patient ranged from } \\
1,822.5 \text { to } 12,150 \mathrm{mg} \\
\text { of pentavalent } \\
\text { antimony and the } \\
\text { treatment time from } 3 \\
\text { to } 10 \text { weeks with } \\
\text { efficacy of } 86 \text { percent. }\end{array}$ & & $\begin{array}{l}\text { valuable alternative } \\
\text { for cases with } \\
\text { potential antimony } \\
\text { toxicity or whose } \\
\text { application of daily } \\
\text { injections represents } \\
\text { an obstacle to } \\
\text { treatment. }\end{array}$ \\
\hline Meneses, 2007 & & $\begin{array}{c}\text { To describe the } \\
\text { epidemiological, } \\
\text { clinical, laboratory, } \\
\text { therapeutic and } \\
\text { evolutionary patterns } \\
\text { (including sequelae) } \\
\text { of the mucosal or } \\
\text { cutaneous mucosal } \\
\text { forms of American } \\
\text { Cutaneous } \\
\text { Leishmaniasis } \\
\text { (ACL) }\end{array}$ & $\begin{array}{l}\text { A total of } 132 \text { medical } \\
\text { records were selected } \\
\text { from patients } \\
\text { attending the } \\
\text { Otorhinolaryngology } \\
\text { Clinic of the Evandro } \\
\text { Chagas Clinical } \\
\text { Research Institute } \\
\text { (IPEC) / Fiocruz, Rio } \\
\text { de Janeiro, between } \\
\text { January 1, 1989 and } \\
\text { December } 31,2004 . \\
\text { The diagnosis was } \\
\text { established based on } \\
\text { epidemiological } \\
\text { criteria, clinical and } \\
\text { laboratory tests, } \\
\text { including response to } \\
\text { Montenegro } \\
\text { intradermalimoration } \\
\text { (IDRM), LTA } \\
\text { serology, } \\
\text { histopathology and } \\
\text { culture. }\end{array}$ & $\begin{array}{l}\text { The nasal cavities were affected } \\
\text { in } 92.4 \text { percent of the cases. The } \\
\text { most frequent aspect of lesions } \\
\text { was mucosal infiltration. The } \\
\text { ulcer was the active cutaneous } \\
\text { lesion predominant in the } \\
\text { cutaneous-mucosal form. }\end{array}$ & $\begin{array}{l}\text { Of the patients that } \\
\text { performed IDRM, } \\
97.4 \text { percent had a } \\
\text { strong reaction. } \\
\text { Indirect } \\
\text { immunofluorescence } \\
\text { serology titers } \\
\text { declined steadily } \\
\text { over two years } \\
\text { posttreatment. In the } \\
\text { histopathology, the } \\
\text { predominant aspect } \\
\text { was the chronic } \\
\text { granulomatous } \\
\text { inflammatory } \\
\text { infiltrate, without } \\
\text { the presence of } \\
\text { amastigotes. }\end{array}$ \\
\hline Lindoso et al 2009 & $\begin{array}{c}\text { British } \\
\text { Journal of } \\
\text { Dermatolog } \\
\text { y }\end{array}$ & $\begin{array}{c}\text { Describe a series of } \\
\text { patients co-infected } \\
\text { with Leishmania and } \\
\text { HIV. }\end{array}$ & $\begin{array}{c}\text { Analysis of medical } \\
\text { records of patients by } \\
\text { demographic data, } \\
\text { clinical } \\
\text { manifestations, } \\
\text { diagnoses, treatments } \\
\text { and results }\end{array}$ & $\begin{array}{l}15 \text { cases of AIDS / LT were } \\
\text { found. Several manifestations } \\
\text { have been found, ranging from } \\
\text { ulcer to polymorphic lesions. } \\
\text { Mucosal lesions were present in } \\
80 \% \text { and cutaneous lesions in } \\
73 \% \text { of the patients. All received } \\
\text { anti-Leishmania therapy and 53\% } \\
\text { relapsed. } 67 \% \text { received highly } \\
\text { active antiretroviral therapy but } \\
\text { did not show differences in } \\
\text { results compared to those who did } \\
\text { not. } 40 \% \text { died during the study } \\
\text { period. }\end{array}$ & $\begin{array}{c}\text { Clinical } \\
\text { manifestations of LT } \\
\text { in patients with HIV } \\
\text { are diverse. The } \\
\text { study emphasizes } \\
\text { possible common } \\
\text { manifestations of the } \\
\text { disease in } \\
\text { seropositives, } \\
\text { especially in severe } \\
\text { cases. }\end{array}$ \\
\hline Figueroa et al 2009 & $\begin{array}{c}\text { Journal of } \\
\text { infectious } \\
\text { diseases }\end{array}$ & $\begin{array}{c}\text { Detection of } \\
\text { Leishmania in the } \\
\text { unaffected mucosae } \\
\text { of patients with } \\
\text { leishmaniasis caused } \\
\text { by Leishmania } \\
\text { (Viannia). }\end{array}$ & $\begin{array}{l}\text { The presence of } \\
\text { Leishmania in the } \\
\text { mucosa of } 26 \text { patients } \\
\text { with cutaneous } \\
\text { leishmaniasis and } 2 \\
\text { with mucocutaneous } \\
\text { leishmaniasis was } \\
\text { evaluated. Samples of } \\
\text { the nasal, tonsil and } \\
\text { connective mucosa } \\
\text { were analyzed using } \\
\text { the polymerase chain } \\
\text { reaction with LV-B1 } \\
\text { primers and Southern } \\
\text { blot hybridization. }\end{array}$ & $\begin{array}{l}2 \text { patients with mucocutaneous } \\
\text { leishmaniasis and } 21 \text { of } 26 \\
\text { patients with cutaneous } \\
\text { leishmaniasis had kinetoplast } \\
\text { (kDNA) present in mucous } \\
\text { membranes. KDNA was detected } \\
\text { in the mucosa of patients with } \\
\text { cutaneous disease. }\end{array}$ & $\begin{array}{l}\text { The presence of } \\
\text { asymptomatic } \\
\text { parasites in the } \\
\text { mucous membranes } \\
\text { may be common in } \\
\text { patients with } \\
\text { Leishmania } \\
\text { infection (Viannia). }\end{array}$ \\
\hline
\end{tabular}

Source: Research Data 


\section{Discussion}

\section{Epidemiology}

The American Tegumentary Leishmaniasis (ATL) is a polymorphic disease on the skin and/or the mucosa that provokes ulcerated injuries, nodular, unique or multiples, caused by protozoa of the genus Trypanosomatidae. The presented disease presents a wide distribution in the country, with registers of cases in all of the brazilian regions. (Viana. G. et al., 2012) The ATL constitutes a Public Health problem. Its importance resides not only in its high incidence and wide geographic distribution, but also in the possibility of taking forms that can determine destructive injuries, disfiguring and also incapacitating, with a big repercussion in the psychosocial field of the individual. (Gontijo and Carvalho, 2003) The World Health Organization (WHO) includes the American Tegumentary Leishmaniasis among the six infectious diseases and priority parasite for control actions.

Human beings are always susceptible, not doing habitually part of the placement chain, can acquire the disease when unbalance, in an intentional way, the primitive forestall ecosystem, in which coexist the reservoir mammal, the vector insects and etiologic agent. (Furtado, 1989) The etiologic agent is a protozoa of the Leishmania genus, transmitted through the sting of insects known as sand flies (Meneses, 2007) The most prevalent species are Leishmania (V.) braziliensis and Leishmania (Leishmania) amazonensis (Cupolillo et al., 2003, Guerra et al., 2011, Lindoso and Linsoso, 2009).

After the transmitting, the evolution can vary from subclinical infections until grave and mutilating mucosa forms, depending on some factors. (Meneses, 2007) The type of the infection is determined by the genus Leishmania, factors of virulence and immunity answer, may result in cutaneous injury, cutaneous or visceral mucosa. The Mexican Leishmania complex and braziliensis are responsible for cutaneous injuries. The subgenus Vianna species is particularly important for the propriety of causing mucosa-cutaneous injuries. (Ameen, M., 2010)

The WHO stipulates, ordinarily, 12 million of Leishmania infections, being about 1,5 million of cases of cutaneous leishmaniasis in the world. From the 80's decade, in Brazil, it is verified the growth in the number of the cases of ATL registered, varying from 3.000 (1980) to 35.748 (1995). It is observed transmission peaks in each five years, presenting tendency in the growth of the number of the cases, starting from 1985, when it solidifies 
the implantation of vigilance actions and the control of ATL in the country. (Oliveira, 2011).

Figure 2. Number of cases of detection of autochthonous cases of ATL Brazil - 1985 to 2003; reproduced of the American Tegumentary Leishmaniasis atlas.

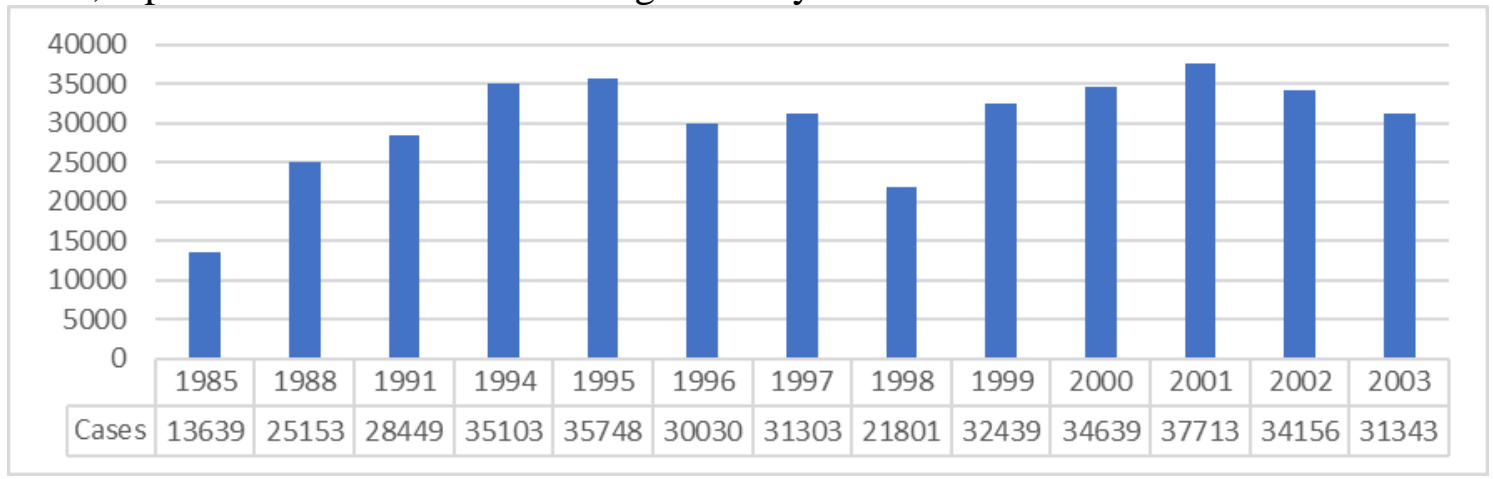

The leishmaniasis prevails more in urban than the rural zones, with a suggestion of bigger occurrence in poor ambient and near to forest. (Meneses, 2007 Oliveira, 2011, Viana A. G. et al., 2012) It must be emphasized the occurrence in the peri-urban profile of transmission, it is related with the lack of basic sanitation, the precarious economic situation, the population migration for the peripheral of the cities, the inappropriate construction materials and the socializing with badland animals or even domesticated that serve as new reservoir of the disease, allied to the growth of the rate population that concentrates in the "deposit" of trash in these areas. (Basano and Camargo, 2004) The occurrence of high numbers of ATL cases between men and adults suggests more extradomiciliar transmission in economically active population, while the occurrence between woman and child suggests the transmission intra and/or peri domiciliary (Viana A. G. et al., 2012). 
Figure 3. Chart with the epidemiologic prevalence of leishmaniosis cases studied in relation to region, gender and age, accordingly to the articles included on results.

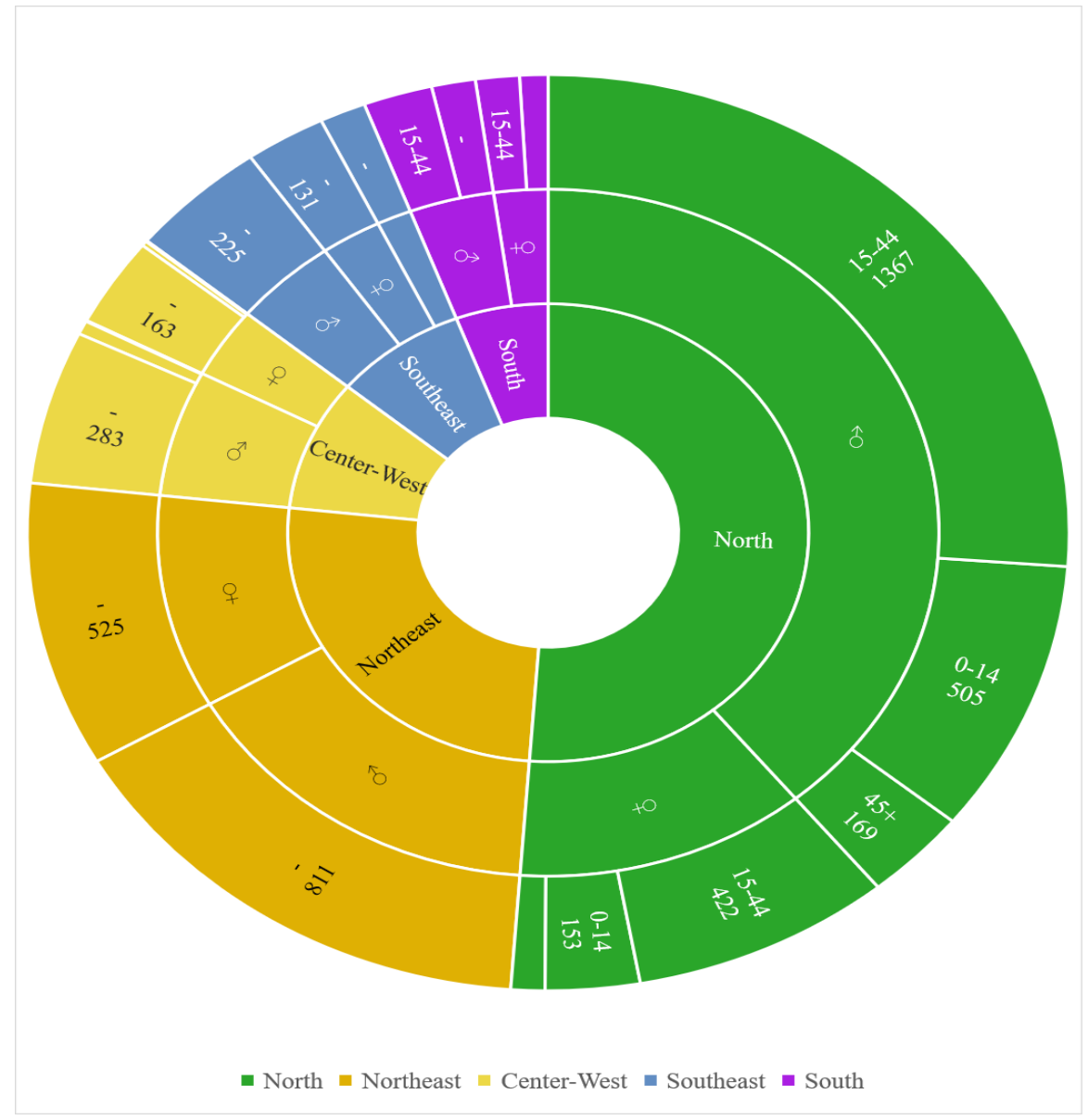

\section{Clinic and Diagnosis}

American Tegumentary Leishmaniasis (ATL) is the name given to the infectious set that causes immunological alterations and polymorphic alterations on the skin and mucosa. Caused by the contamination with the protozoa in the genus Leishmaniasis, the pathogen in question can manifests itself in the tegumentary forms (mucosa and cutaneous) and in the visceral form, depending on the parasite and the affected host (Oliveira, 2011; Padilha; Albuquerque; Pedrosa, 2010).

There is in the American continent, more than 11 types of responsible species by the surging of the disease. In Brazil the dermotropic species more frequently founded are L. braziliensis, L. amazonensis and L. guyanensis, respectively. The cutaneous form of the 
disease can be classified in located, disseminated and diffuse, varying accordingly with the local and with the amount of existent injuries (Braga, 2012).

The Located Cutaneous Leishmaniasis (LCL) is characterized by the appearing of papules with the evolution for the painless injuries with high borders well delimited, that appears generally in location of easy access to the transmitter insect. Besides that, the commonly ulcer presents rounded and reddish aspect and grainy coarse and can regress in the absence of treatment in a period of 15 months after its emergence (Oliveira et al., 2016; Murback et al., 2011).

In the Disseminated Cutaneous Leishmaniasis (DCLi), the injuries appear in bigger amount and spreads for all the cutaneous surface in a disorder form, simulating an aspect of unique injury. The Diffuse Cutaneous Leishmaniasis (DCL) it is differentiated of the other cutaneous forms because besides being rarer, it will present, with the disseminated injuries, the presence of infiltrations and tubercles in body areas very extended. Besides, the DCL possess a bad answer to the existent treatments, differently from the LCL and DCLi (Costa, 2014; Dorta et al., 2012).

Accordingly, to Martínez-Valência et al. (2017) and with Gomes et al. (2014), the most important characteristic of Mucosa Leishmaniasis (LM) is the appearing of invasive injuries in the respiratory paths. These, generally, are associated to the deformity and the destruction of facial structures, mainly septum nasal and most rarely mucosa on the mouth, pharynx and larynx. The LM tends to affect individuals that don't treat correctly the LC and it is associated to the lymphatic dissemination of the parasite. The patients commonly complain of symptoms with nasal obstruction, total sensibility, epistaxis, dysphagia, and others. It is important to salient that the existent injuries in the mucosa form of the disease are progressive and rarely regress spontaneously.

The diagnosed of Leishmaniasis is characterized as laboratorial, clinic and epidemiologic, seen that in the progress of diagnose must be observed, besides the clinical and laboratorial signs, if the patient resides or frequent recently endemic areas of the disease. The confirmation of the disease it is given through the realization of parasitological exams that permits to observe the presence of the parasite (RUS, 2014). There is a big number of laboratorial exams employed actually in the diagnosed of ATL like it is possible to observe in the Table 2. 
Table 2: Most used laboratory tests, specifying their principles, methodologies, percentage of effectiveness and occurrence of cross-reaction (Ministry of Health, 2017).

\begin{tabular}{|c|c|c|c|c|}
\hline \multicolumn{5}{|c|}{ Laboratorial Diagnosis } \\
\hline Test & Via & Methodology & Eficacy & $\begin{array}{c}\text { Cross } \\
\text { reaction }\end{array}$ \\
\hline Biopsy & Parasitological & $\begin{array}{l}\text { Removal of cellular material or a tissue fragment } \\
\text { from a living being for analysis. }\end{array}$ & $89 \%$ & Absent \\
\hline Culture & Parasitological & Culture in vivo. & $95 \%$ & Absent \\
\hline ELISA & Sorological & $\begin{array}{l}\text { Teste imunoenzimático que permite a } \\
\text { detecção de anticorpos específicos. }\end{array}$ & $90 \%$ & Common \\
\hline IFI & Sorological & $\begin{array}{l}\text { A technique that allows the visualization of } \\
\text { antigens through the use of specific antibodies } \\
\text { labeled with fluorochrome, capable of emitting } \\
\text { light at a certain wavelength, allowing their } \\
\text { observation under a fluorescence microscope. }\end{array}$ & $90 \%$ & Common \\
\hline PAAF & Parasitological & $\begin{array}{l}\text { The practitioner inserts a fine needle in the region } \\
\text { and removes some cells that will be sent to the } \\
\text { laboratory and analyzed. }\end{array}$ & $89 \%$ & Absent \\
\hline PCR & Molecular & $\begin{array}{l}\text { Amplification of the parasite DNA in different } \\
\text { types of samples. }\end{array}$ & $94 \%$ & Absent \\
\hline $\begin{array}{l}\text { Lesion } \\
\text { scraping }\end{array}$ & Parasitological & $\begin{array}{l}\text { Microscopic visualization of the evolutionary forms } \\
\text { of the parasite after scraping of the lesion. }\end{array}$ & $80 \%$ & Absent \\
\hline RIDM & Immunological & $\begin{array}{l}\text { Immune response developed after contact with the } \\
\text { protozoan. }\end{array}$ & $\begin{array}{l}80 \%- \\
100 \% \%\end{array}$ & Absent \\
\hline $\begin{array}{l}\text { Western- } \\
\text { Blot }\end{array}$ & Sorological & $\begin{array}{l}\text { This technique uses gel electrophoresis to separate } \\
\text { the native proteins from the parasite. }\end{array}$ & $100 \%$ & Unusual \\
\hline
\end{tabular}

Vaconcellos (2013) affirms that the fundamental diagnostic of leishmaniasis consists in the realization of pathological exams, immunological and molecular. Among the parasitological tests more commonly realized, stand out the biopsy accompanied by histopathology conventional or immunohistochemica, scraping injury and aspired by fine needle (PAF), these permits the direct visualization of the parasite and therefore are the tests of first choice.

The immunological tests, act in an indirect form because it possibilities the visualization of immunological answer existents in the disease. The intradermic reaction of Montenegro (IRM) it is the most known exam and most realized, followed by serological exams of ELISA and indirect immunofluorescence. The IRM permits the answer visualization of the later hypersensitivity against the antigens of the 
Leishmaniasis, while the serological tests evidence the existent antibodies against the parasite in question (Cerutti et al., 2017; Menezes-Souza et al., 2015).

The molecular diagnostic made by the chain reaction of polymerase (CRP) is considered the most sensible and effective, therefore its high cost and methodology more complicated don't permit that it is widely realized (Ferreira; Gomes; Pereira-Chioccola, 2015).

\section{Therapy}

In the treatment for ATL with impairment of the mucosa the antimonies pentavalents are the first-choice treatment indicated by the Health Ministry. The patients with mucosa injuries must utilize $20 \mathrm{mg} \mathrm{Sb5+/kilo/day} \mathrm{for} 30$ days, respecting the maximum limit of 3 dailies ampoules. The use of these drugs has been associated to adverse effects, mostly in the most elevated age range, and in the mucosa form. As second line medicaments it is indicated Anfotericine B and Pentamidine when there is no possibility of the use of antimonies or when the answer with the utilization of this isn't satisfactory. (Costa et al., 2014)

Studies from Velozo et al. (2006) approached a relate of a child's case with the age of 5 years impaired with ATL and mucosa, nasal and oral injuries, submitted to the initial treatment with the antimony pentavalent of $20 \mathrm{mg} \mathrm{SbV} / \mathrm{kg}$ in alternate days (23 days) by Pediatrics. With the surging of new injuries, it was administrated amphotericin B liposomal in the total doses of $517 \mathrm{mg}$, presenting growth in the urea and creatinine, decay of a general state and aggravation of the injuries, afflicting nose, lips, hard and soft palate, periorial region and right malar. The patient ended being afflicted for secondary infections, being taken to sepsis and obit. The author didn't consider satisfactory the treatment with the antimony pentavalent, however incomplete, being recurrence documented even after the patronized treatment. As the amphotericin B, he considered, even with applied adequate doses, that there are many therapeutic flaws.

In the researches of Amato et al. (1996) made with 10 patients impaired with mucosa injuries, being five of the patients compromising the nasal cavities, four of the nasal cavities and oropharynx and one of the palate caused for ATL, interned in the Division of Infectious and Parasitic Diseases from the Hospital of Clinics, of the Medicine College of the University of São Paulo and in the Public Server Hospital of the State "Francisco Morato de Oliveira", and treated with isethionate of pentamidine in the dose of $4 \mathrm{mg} / \mathrm{kg}$ in 
alternate days intravenous way, $90 \%$ of the patients that finalized the treatment have had complete cicatrization of injuries without recurrence in the period of accompaniment from 1 to 24 months. The isethionate of pentamidine is well absorbed and stays, after a unique dose, detectable in the blood only during a short period being excreted slowly for the kidneys, presenting restrictions only with relation to the tolerance of the patients. Against this the precarious answers of the antimonies with relation to the impairment of the mucosa referred by the author, he pointed out the necessity of a better evaluation of pentamidine in the treatment of the mucosa injuries of ATL, mainly, to verify if it produces less recurrence than the antimonies.

The application of the treatment with pentavalents antimonies in 4 related cases of patients from the equatorial coast with ATL and mucosa injuries, mostly nasal and oral, by Ronquillo et al. (2012) shows itself satisfactory, being the response evaluated with the disappearing of activity signs, ulceration, erythema and, finally, fibrous cicatrization with permanent sequels. The pentavalent antimonies were considered, a therapy of choice.

In the studies of Costa et al. (2014), 78 patients impaired with ATL and oral mucosa affected were evaluated, being $93,7 \%$ treated with antimonies of meglumine, 3,4\% with amphotericin B and 2,9\% with other drugs. It was observed a bigger number of recurrences and lesser frequency of finalization and healing until a year later the treatment in these patients with buccal commitment. The presence of an oral injury in ATL also has been associated to a high alimentary deficit, with consequent malnutrition and difficulty in the healing of the injuries. The use of small doses of antimoniate of meglumine presented itself efficient in the treatment of patients with an oral localization. However, the results of these studies suggested that the oral involving in ATL is relate to worsts therapeutic results and may be considered as a factor of worst prognosis in its mucosa form.

Meneses et al. (2007 related a study with 128 patients, that realized a treatment in the Leishmaniasis Reference Center - IPEC/ Fiocruz, with mucosa form of ATL, being 92,4\% of the cases with the nasal cavity impaired. $86 \%$ of the patients were treated with a lower doses of antimoniate of meglumine ( $5 \mathrm{mg} \mathrm{Sb5+/} \mathrm{kg} /$ day), with a good response to the treatment and lesser adverse effects, including the cases re-treated by recurrence and therapeutic flaw, being 79 submitted to the continuous scheme treatment, application for 30 days uninterrupted, and 31 to the scheme in series of 10 days with equal breaks without application. The majority of the adverse effects was soft and transitory or absents, mainly in the patients submitted to the continuous treatment. It is suggested that the use of high doses for the treatment of the mucosa form of ATL, as is regulated for the WHO, is 
responsible for the most problematic adverse events, because in this study the majority of the submitted patients to lower doses didn't present meaning side effects.

In the studies of Ruas et al. (2014) in the Clinical Research Institute Evandro Chagas (IIPEC) with 16 treated patients of ATL associated to diverse mucosa injuries, mostly nasal $(93,8 \%), 11$ patients were impaired with vocal alterations, suggesting that the exclusive medicated treatment can be insufficient to the reestablishing of the voice. The number of sessions of speech therapy varied from 1 to 18 , being $81 \%$ has frequented between 2 and 10 sessions. 6 patients presented significant general improvement; the rest of the patients stayed with some functional alteration though with a lower grade of intensity. The speech therapy rehabilited $71 \%$ of the patient's sequels. It is pointed out the necessity of a strategy implantation of speech therapies intervention in the post-treatment of the patients with mucosa injuries accordingly to this study.

Studies from Guedes et al. (2014) with rats BALB/c immunized intranasally with serine protease partially purified starting from extracts of soluble promastigotes (LaSP-Sol) and extracellular (LaSP-Ex) of amazonensis Leishmania before the infection by L. amazonensis, considering an effective form and non-invasive of inducing the active immunity against infectious agents, that enters the body through the mucosa, the local tolerance and the peripheral to antigens, showed that an antigen more defined, protease serine extracellular of L. amazonensis, is protector by intranasal way encouraging additional searches in this second generation vaccine. And in the relates of Seyed et al. (2016) the reverse vaccinology shows itself as a prophylaxis form more promising because through the genomic comparative or subtractive field it reduces the time to the development of attenuated live attenuated vaccines, once there is an availability of the genomic sequences of pathogenic cepes e non-pathogenic.

Researches of Hugentobler et al. (2012) realized with rats BALB/c using the oral immunization with live Lactococcus lactis co-expressing LACK and IL-12 showed protection against the Leishmania major subsequent. This vaccination induced to the antibodies production in the mucosa and answers T H 1 specific and systemic of LACK. This protection showed as a prophylactic promising form for relating itself with the generation of the answer T $\mathrm{H} 1$ specific against the Leishmania. 


\section{Conclusion}

The Tegumentary Leishmaniasis represents an expressive problem of world public health. In this vies, the epidemiologic studies descript referred that the prevalence of LT is notoriously related to the socioeconomic conditions of the populations, expressing the necessity of the development of jurisprudences that intensifies the care with the public health.

So, it's indispensable the conception and application of measures that strengthen the universal access to the health public services and the progress of education projects in health. Beyond that, the standardization of therapeutic procedures with the election of easy administration chemotherapeutics and low risk and cost for the ill. It is appropriated also the intensifying the governmental aids to the research and for the development of new antiparasitic drugs, beyond the epidemiologic analyzes studies that possibilities the planning and professional actuation in front of the TL.

\section{Refererences}

Amato, Valdir Sabbaga et al. (1996). Tratamento da Leishmaniose tegumentar americana, com lesão em mucosa, por meio do isotionato de pentamidina. Rev. Soc. Bras. Med. Trop., Uberaba, 29, (5) p. 477-481, out.

Ameen, M. (2010). Cutaneous leishmaniasis: advances in disease pathogenesis, diagnostics and therapeutics. Clinical And Experimental Dermatology, [s.1.], v. 35, n. 7, p.699-705, 10 set. Wiley.

Basano, S. de A.; Camargo, L. M. A. (2004). Leishmaniose tegumentar americana: histórico, epidemiologia e perspectivas de controle. Rev. bras. epidemiol., São Paulo , 7(3), p. 328-337, Sept.

Bevenuto Junior, P. (2000). Geografia e ecologia da Leishmaniose Tegumentar no Estado do Espírito Santo. Rio de Janeiro, s.n; 2000. 68 p. ilus, mapas, graf. Retrieved from: <https://www.arca.fiocruz.br/bitstream/icict/4939/2/173.pdf>. accessed in 26 out. 2018. http://pesquisa.bvsalud.org/brasil/resource/pt/lil-273050.

Braga, F. P. B. (2012). Estudo da orelha média na forma mucosa de leishmaniose tegumentar americana. 2012. 70 f. Tese (Doutorado) - Curso de Ciências, Fundação Oswaldo Cruz, Instituto de Pesquisa Clínica Evandro Chagas, Rio de Janeiro. 
Brown, Daniel R. et al. (1996). [32-Microglobulin-dependent NKI.1 + T Cells Are Not Essential for T Helper Cell 2 Immune Responses. The Journal of Experimental Medicine, Illinois, 184, p. 1295-1304, out.

Camargo-Neves, V. L. F. de; Gomes, A. de C.; A, J. L. F. (2002). Correlação da presença de espécies de flebotomíneos (Diptera: Psychodidae) com registros de casos da leishmaniose tegumentar americana no Estado de São Paulo, Brasil. Rev. Soc. Bras. Med. Trop., Uberaba, 35(4) p. 299-306, Aug.

Castro, E. A. de et al. (2002). Estudo das características epidemiológicas e clínicas de 332 casos de leishmaniose tegumentar notificados na região norte do Estado do Paraná de 1993 a 1998. Rev. Soc. Bras. Med. Trop., Uberaba, 35(5), p. 445-452, Oct.

Cerutti, P. H. P. et al. (2017). Métodos diagnósticos da leishmaniose tegumentar Americana: uma revisão de literatura. Revista de Patologia do Tocantins, v. 4, n. 4, p.5559, 28 nov. Universidade Federal do Tocantins.

Costa, D. C. S. da. (2014). Caracterização clínica e laboratorial das manifestações orais de Leishmaniose Tegumentar Americana. 2014. 75 f. Dissertação (Mestrado) Curso de Pesquisa Clínica em Doença Infecciosas) - Instituto Nacional de Infectologia Evandro Chagas, Rio de Janeiro.

Cupolillo, E. et al. (2003). Genetic Polymorphism and Molecular Epidemiology of Leishmania (Viannia) braziliensis from Different Hosts and Geographic Areas in Brazil. Journal Of Clinical Microbiology, [s.1.], 41(7), p.3126-3132, 1 jul. American Society for Microbiology.

DF. Ministério da Saude. . (2006). Atlas de Leishmaniose Tegumentar Americana: Diagnósticos clínico e diferencial. Brasília: Editora Ms.,136 p.

Dorta, M. L. et al. (2012). Improvements in obtaining New World Leishmania sp from mucosal lesions: Notes on isolating and stocking parasites. Experimental Parasitology, [s.1.],132(2), p.300-303.

Enciso, Alfredo et al. (2000). Comprometiendo la estructura osteo-facial de las poblaciones humanas del Antiguo Perú por la Leishmaniasis Tegumentaria de forma mucosa. Rio de Janeiro, s.n; 2000. 213 p. ilus, mapas, tab. Retrieved from: $<$ http://portalteses.cict.fiocruz.br/transf.php?script=thes_cover\&id=000108\&lng=pt\&nrm= iso >. accessed in 26 out. 2018. http://pesquisa.bvsalud.org/brasil/resource/pt/lil-276650. Ethiopia. Organização Mundial da Saúde. . Report of the Fifth Consultative Meeting on Leishmania/HIV Coinfection. Addis Ababa, 2007. 29 p.

Ferreira, L. T. ; Gomes, A. H. S. ; Pereira-Chioccola, V. L. (2015). Genotype characterization of Leishmania (Viannia) braziliensis isolated from human and canine biopsies with American cutaneous leishmaniasis. Rev. Inst. Med. Trop. São Paulo, v. 57, n.3, p. 257- 262.

Furtado, Tancredo Alves. Tratamento da leishmaniose tegumentar americana, com lesão em mucosa, por meio do isotionato de pentamidina. Amato Neto y Baldy Jls (eds) Doenças Transmissíveis, São Paulo, n. 3, p.553-557, 1989. 
Galdino, H.J. et al. Interleukin $32 \gamma$ (IL-32 $\gamma$ ) is highly expressed in cutaneous and mucosal lesions of American Tegumentary Leishmaniasis patients: association with tumor necrosis factor (TNF) and IL-10. Bmc Infectious Diseases, Goiás, v. 14, n. 249, p.1-13, 2014.

Garcia, Flávio C. B. et al . (2005). Métodos subsidiários para o diagnóstico da Leishmaniose tegumentar americana (LTA): comparação dos resultados do seqüenciamento de DNA e da PCR-RFLP para determinação da espécie de leishmania em amostras cutâneo-mucosas. An. Bras. Dermatol., Rio de Janeiro, v. 80, supl. 3, p. S339S344, Dec.

Gomes, C. M. et al. (2014). Complementary exams in the diagnosis of American tegumentary leishmaniasis. Anais Brasileiros de Dermatologia, v. 89, n. 5, p.701- 711.

Gontijo, Bernardo; Carvalho, Maria de Lourdes Ribeiro de. Leishmaniose tegumentar americana. Rev. Soc. Bras. Med. Trop., Uberaba, 36(1) p. 71-80, jan. 2003.

Guerra, Jorge Augusto de Oliveira et al. Mucosal Leishmaniasis Caused by Leishmania (Viannia) braziliensis and Leishmania (Viannia) guyanensis in the Brazilian Amazon. Plos Neglected Tropical Diseases, [s.1.], v. 5, n. 3, p.980-980, 8 mar. 2011. Public Library of Science (PLoS).

Lindoso, José A. L. et al. (2009). Unusual manifestations of tegumentary leishmaniasis in AIDS patients from the New World. British Journal of Dermatology, 160(2): 311-8, fev.

Lindoso, José Angelo L.; Lindoso, Ana Angélica B.p. (2009). Neglected tropical diseases in Brazil. Revista do Instituto de Medicina Tropical de São Paulo, [s.1.], 51(5), p.247-253, out. FapUNIFESP (SciELO).

Martínez-Valencia, A. J. et al. (2017). Clinical and parasitological factors in parasite persistence after treatment and clinical cure of cutaneous leishmaniosis. Plos Neglected Tropical Diseases, [s.1.], 11(7), p.1-15, 13 jul. Public Library of Science (PLoS).

Meneses, A. M. de. (2007). Perfil epidemiológico, clínico e terapêutico dos pacientes com a forma mucosa de leishmaniose tegumentar americana, atendidos no Instituto de Pesquisa Clínica Evandro Chagas - Fundação Oswaldo Cruz, Rio de Janeiro, no período de 1989 a 2004. Rio de Janeiro; s.n; 114 p. graf., 2007.

Menezes-Souza D. et al. (2015). Improving Serodiagnosis of Human and Canine Leishmaniasis with Recombinant Leishmania braziliensis Cathepsin Like Protein and a Synthetic Peptide Containing Its Linear B-cell Epitope. PLoS Negl Trop Dis, v.9, n.1, p. 3426.

Muñoz S. I. S. et al. (2002). Revisão sistemática de literatura e metanálise: noções básicas sobre seu desenho, interpretação e aplicação na área da saúde. In: Anais do $8^{\circ}$ Simpósio Brasileiro de Comunicação em Enfermagem; nov 6-11; São Paulo, Brasil [CD- ROM]. São Paulo:Universidade de São Paulo.

Muñoz S. I. S. et al. (2002). Revisão sistemática de literatura e metanálise: noções básicas sobre seu desenho, interpretação e aplicação na área da saúde. In: Anais do $8^{\circ}$ Simpósio 
Brasileiro de Comunicação em Enfermagem; 2002, nov. 6-11; São Paulo, Brasil [CDROM]. São Paulo: Universidade de São Paulo.

Murback, N. D. N. et al. (2011). Leishmaniose tegumentar americana: estudo clínico, epidemiológico e laboratorial realizado no Hospital Universitário de Campo Grande, Mato Grosso do Sul, Brasil. Anais Brasileiros de Dermatologia, Campo Grande, 86(1), p.55-63.

Oliveira, A. C. M. (2011). Caracterização epidemiológica da Leishmaniose Tegumentar Americana no município de Rio Branco-Acre no período de 2000 a 2008. 2011. 51 f. Dissertação (Mestrado) - Curso de Saúde Pública, Escola Nacional de Saúde Pública Sergio Arouca, Rio de Janeiro.

Oliveira, A.G.L. et al. (2013). Influence of the nutritional status in the clinical and therapeutical evolution in adults and elderly with American Tegumentary Leishmaniasis. Acta Tropica, [s.1.], 128 (1), p.36-40, out.

Oliveira, F. S. (2011). Estudo clínico-molecular na leishmaniose mucocutânea: Diagnóstico e Rastreamento de Subpopulações de Leishmania (Viannia) braziliensis nos níveis inter e intrapacientes. $101 \mathrm{f}$. Tese (Doutorado) - Curso de Ciências, Instituto de Pesquisa Clínica Evandro Chagas, Fundação Oswaldo Cruz Instituto de Pesquisa Clínica Evandro Chagas, Rio de Janeiro.

Oliveira, R. Z. et al. (2016). Leishmaniose tegumentar americana no município de Jussara, estado do Paraná, Brasil: série histórica de 21 anos. Espaço Para A Saúde - Revista de Saúde Pública do Paraná, v. 17, n. 2, p.59-65, 29 dez. 2016. Instituto de Estudos em Saúde Coletiva - INESCO.

Oliveira-Neto, M. P. de; Mattos, M. da S. (2006). An alternative antimonial schedule to be used in cutaneous leishmaniasis when high doses of antimony are undesirable. Rev. Soc. Bras. Med. Trop., Uberaba,39(4), p. 323-326, Aug.

Padilha, B. G.; Albuquerque, P. V. V.; Pedrosa, F. A. (2010). Indicadores epidemiológicos da leishmaniose tegumentar americana, no período de 1999 a 2008, no Estado de Alagoas, Brasil. Revista Pan-amazônica de Saúde, [s.1.], 1 (3), p.95-102, set.

Ruas, A.C. N. (2014). Estudo prospectivo intervencional de terapia fonoaudiológica vocal na leishmaniose mucosa. 2014. 67f. (Tese (Doutorado) Curso de Pesquisa Clínica em doenças infecciosas- Instituto Nacional de Infectologia Evandro Chagas, Fundação Oswaldo Cruz, Rio de Janeiro.

Serra, Cathia M. B. et al . (2003). Leishmaniose tegumentar canina em Morada das Águias (Serra da Tiririca), Maricá, Rio de Janeiro, Brasil. Cad. Saúde Pública, Rio de Janeiro, 19 (6), p. 1877-1880, Dec.

Vasconcellos, E. C. F. (2013). Tratamento intralesional da leishmaniose cutânea com antimoniato de meglumina no instituto de pesquisa clínica Evandro Chagas, Fiocruz, rio de janeiro (2002 a julho 2011). 2013. 92 f. Tese (Doutorado) - Curso de Pesquisa Clínica em Doenças Infecciosas, Fundação Oswaldo Cruz, Instituto de Pesquisa Clínica Evandro Chagas, Rio de Janeiro. 
Viana, A. G. et al. (2012). Aspectos clínico-epidemiológicos da leishmaniose tegumentar americana em Montes Claros, Minas Gerais. Revista Médica de Minas Gerais, Minas Gerais, 22(1), p.1-28.

\section{How to cite this article (APA format):}

Feitosa, Pedro Walisson Gomes; Oliveira, Italo Constancio de; Moura, Rayane da Silva; Grangeiro, Yasmin de Alencar; Rodrigues, Elisa Hellen Cruz; Caracas, Heloísa Fernandes; Pinheiro, Sally de França Lacerda (2019). Mucosal Injuries by Tegumentary Leishmaniasis: epidemiological, clinical, diagnostic and therapeutic aspects. Am. In. Mult. J., October. (7) 4, 3758.

Received: 19/09/2019

Accepted: 08/10/2019 